\section{E-LOGOS}

ELECTRONIC JOURNAL FOR PHILOSOPHY ISSN 1211-0442

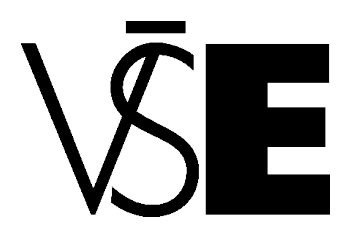

University of Economics

Prague

\title{
Combating Rationalism and 'Blackism' in the Thought of Black Conservative George S. Schuyler
}

Jack Kerwick

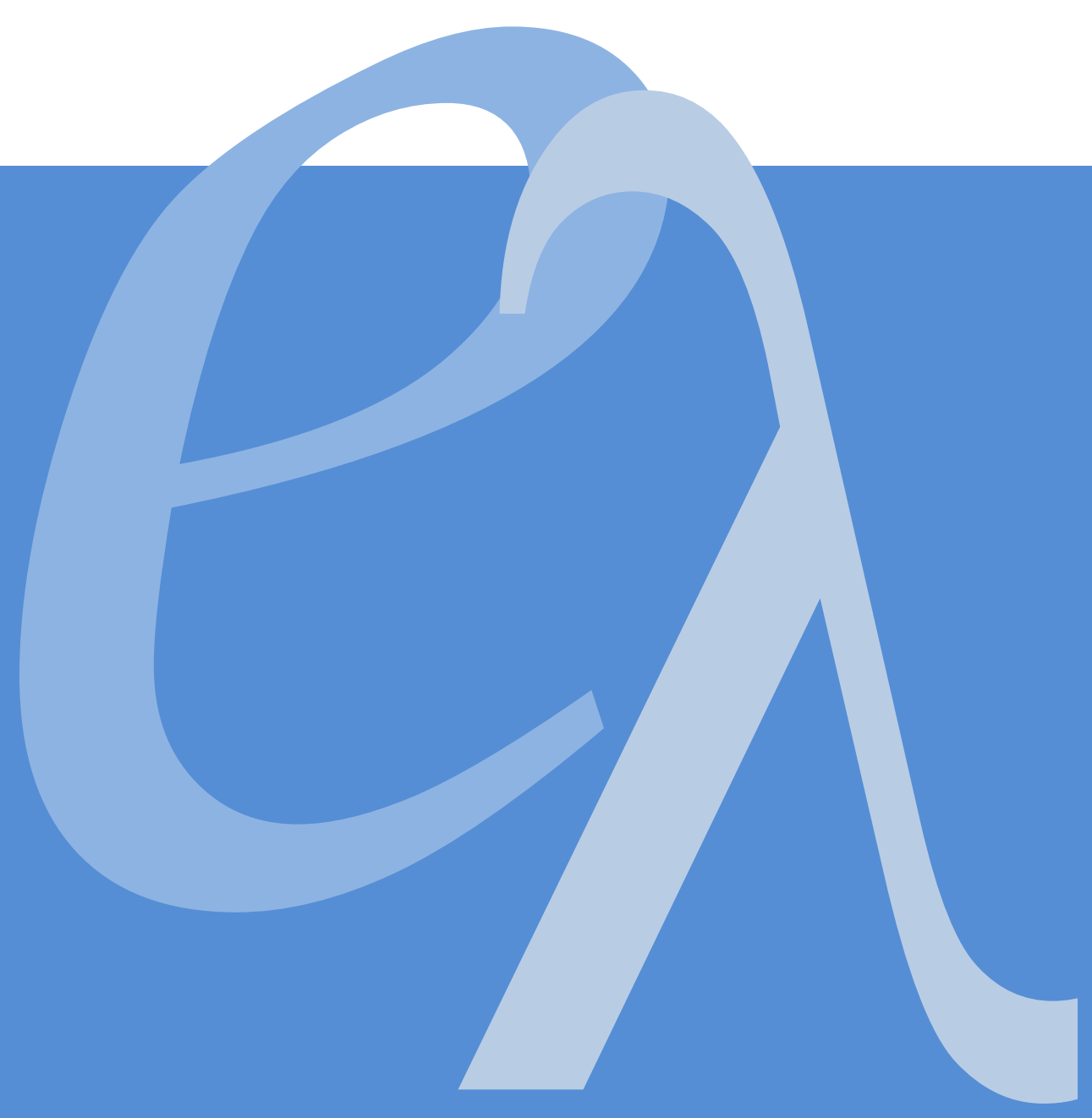




\begin{abstract}
I argue that Schuyler-one of the most prolific American cultural commentators, white, black, or other, of the middle of the 20th century - is grossly misunderstood by his contemporary critics. Far from being the opportunistic political polemicist who was insensitive to the precarious situation of race relations in America that his detractors make him out to be, Schuyler was a sophisticated thinker well educated in the philosophical tradition known as conservatism. Though not a philosopher by trade, he articulated and defended epistemological, ethical, and political-philosophical suppositions long endorsed by such notable conservative theorists as Edmund Burke and Michael Oakeshott. And like the latter, he advanced conservatism in response to a philosophical orientation - rationalism - that conservatives have always recognized as being diametrically opposed to their own. The specific version of rationalism on which Schuyler set his sights is what I call "Blackism" - an abstract ideology that, he believed, undermined racial harmony by neglecting the concrete realities of race relations past and present. As an antidote to Blackism, Schuyler advanced his conservatism.
\end{abstract}

Keywords: George S. Schuyler, rationalism, 'Blackism', Black Conservative. 


\section{Introduction}

For his prodigious efforts in assembling the essays of forgotten "black conservative" George Samuel Schuyler, as well as for his recognition of the latter's considerable talents in his capacities as both writer and thinker, Jeffrey B. Leak deserves much credit. ${ }^{1}$ Leak does not share the political and philosophical predilections of the subject of his study, a fact that reveals his treatment of Schuyler to be that much more commendable. This praise aside, though, Leak's own ideological biases conspire with an all too typically provincial focus on American intellectual and political life to reinforce the very prejudices against the "black conservatism" represented by the likes of Schuyler that Leak presumably set out to dispel.

While acknowledging Schuyler's adeptness at dealing with race-related issues throughout his long and illustrious career, Leak simultaneously criticizes him for "his unshakable commitment at times to the most extreme forms of conservatism," " political far right" or "radical conservatism"3, a commitment that rendered him vulnerable to the charge-articulated by, among others, the distinguished black historian, E. Franklin Frazier - that Schuyler was a "race traitor." 4 Although Leak refuses to endorse this allegation, and although he agrees with Cornel West ${ }^{5}$ that conservatives like Schuyler are correct in rejecting "blind" loyalty to race, he also concurs with West's verdict that black conservatives tend to substitute for "blind loyalty to the race" a "blind loyalty to the nation." Schuyler, in Leak's estimation, was particularly guilty of this as he devoted his energies toward "extreme forms of conservative idealism rather than racial justice." 6 Schuyler's "conservative ideology" became increasingly "uncompassionate," "reactionary," and "insensitive and misguided;"7 it embodied an "excess" 8 of "regrettable polemics"9 and a profoundly "compromised....critical sensibility." 10

Leak is mistaken. In what follows, I argue that while Schuyler was indeed a conservative, he was not the reactionary ideologue of Leaks' imagination. Rather, Schuyler drew upon the resources of a rich, and richly heterogeneous, centuries-old European intellectual tradition now widely regarded as "conservatism." And he drew upon it in order to combat what he perceived to be the folly, not of "black liberalism," but of that of his opponents' rationalism, another specifically European intellectual tradition with roots stretching back even further than the conservatism that it initially elicited as a response. The version of rationalism upon which Schuyler set his sights is what I have chosen to call "Blackism," an ideology that purports to supply the key to "racial authenticity" - and which he believed threatened to undermine racial harmony.

This paper is divided into four sections. In the first, I provide a summary of rationalism, and in the second, the principles of Blackism are delineated. The third 
section is reserved for a summary of conservatism, while the fourth is an exposition of Schuyler's location within this tradition.

\section{Rationalism}

Rationalism has assumed many forms over its extensive and varied life. Yet while it is not inappropriate to speak of multiple rationalisms, each is related to all of the others by way of a set of commonly shared philosophical presuppositions epistemological, ethical, and political-philosophical - on account of which rationalism is the distinctive tradition that it is.

\section{Reason and Knowledge}

In Michael Oakeshott's perceptive exposition of rationalism, he notes that the latter springs from a peculiar conception of knowledge. Knowledge is of two kinds, "technical" and "practical," or "traditional," Oakeshott writes. Although every conceivable activity encompasses both, the proponent of rationalism tends to identify the whole of knowledge with technical knowledge. The latter has the advantage, or at least appears to have the advantage, over traditional knowledge in that, being "susceptible of formulation in rules, principles, directions, maximscomprehensively, in propositions," it conveys "at least the appearance of certainty...."11 "Technical knowledge," Oakeshott continues, "can be learned from a book" or "a correspondence course"; in other words, "it can be learned by heart, repeated by rote, and applied mechanically...." Simply put, technical knowledge "can be both taught and learned in the simplest meanings of these words." 12

In glaring contrast, traditional knowledge "exists only in use, is not reflective and (unlike technique) cannot be formulated in rules."13 The "normal expression" of practical or traditional knowledge is located "in a customary or traditional way of doing things...." This, in turn, "gives it the appearance of imprecision and consequently of uncertainty, of being a matter of opinion, of probability rather than truth." This kind of knowledge lacks "rigidity." It "can neither be taught nor learned, but only imparted and acquired" through "practice."14

For the rationalist, technical knowledge is synonymous with knowledge itself. In conceiving knowledge as a technique, the rationalist opts for an "ideology" over a tradition of conduct, and he makes this choice because of the ideology's "greater precision and its alleged demonstrability," 15 "its appearance of being self-contained." 16 An ideology or technique conveys "the appearance of certainty." 17

\section{Ethics \& Political Philosophy}

Inseparable from the rationalist's epistemic vision is his vision of political-morality. "The morality of the Rationalist is the morality of the self-conscious pursuit of moral 
ideals" and the "moral education" that he prefers assumes the form of "the presentation and explanation of moral principles"18 - like the principles of "natural" or "human rights" found in the Declaration of Independence. ${ }^{19}$ The principlescentered morality of rationalism is an ideology or technique, more specifically, "the morality of the self-made man and the self-made society...."20

As far as politics are concerned, the rationalist's penchant is for "destruction and creation" - not "acceptance or reform." This is because either by design or through inadvertence, he equates change with that which is "self-consciously induced...." As a result, he identifies "the customary and the traditional with the changeless." 21

This conception of change, coupled with his desire to bring it about, conspire to engender the rationalist's faith in both the possibility of "an innocuous power which may safely be made so great as to be able to control all other powers in the human world," as well as his confidence "that political machinery can take the place of moral and political education." 22 It isn't necessarily the case that the thought of the rationalist is "governed in each occasion by a comprehensive utopia;" however, the rationalist is "invariably...a perfectionist in detail." 23 Examples of the rationalist's political philosophy abound. The idea that whole societies can be erected upon "a Declaration of the Rights of Man," is one. Others are notions of such "universal principles" as "national" or "racial self-determination...."24

\section{Blackism}

Like all ideologies, what I refer to as "Blackism" is what Oakeshott described as a technique. And as is the case with all ideologies, the knowledge that it purports to provide is comprised of propositions with which anyone can become familiar. However, while anyone, in theory, can confine the tenets of Blackism to memory, only a person who is biologically black can become a Blackist. Being racially or biologically black - to any extent - is a necessary condition that must be met before one can become a proponent of Blackism, but it is also sufficient. It is crucial to grasp this, for what it means is that subscription to Blackism does not require fluency in black culture. In fact, it is not a stretch to say that it is a contrivance for which precisely those blacks who crave racial "authenticity" but who have not immersed themselves in black culture are the principal beneficiaries. This being said, there most certainly is a relationship between black culture and Blackism, yet it is the same relationship that exists between any ideology and the tradition or practice of which it is the distillation: Blackism stands in relation to black culture as a set of cliff notes stands in relation to the text of which it is the abridgment. Blackism draws from aspects of black culture or "the black experience" in America, but, like the caricature that it is, it wildly distorts the dimensions to which it speaks. 
So, what is Blackism? The ideology of Blackism is distinguished on account of five mutually supplementary features, principles, or themes. This list of features is more impressionistic than exhaustive, and Blackists may and do disagree as to which warrant greatest emphasis. However, consideration of Blackism brings to light the following.

The first is the linchpin of its worldview: the Blackist's racialized conception of history. On this conception, historical actors are abstract racial categories - whites, blacks, etc. - and history itself is a melodramatic contest between the forces of "white racism" or "white supremacy," on the one hand, and "the oppression" suffered by "people of color," on the other. It is not a stretch to characterize Blackist "history" as a species of solipsism, for in spite of the nods that it occasionally gives in the way of black suffering in other parts of the world, it largely coalesces around a truncated vision of the American past and present: time essentially begins and ends within the American mind.

The second principle of Blackism, clearly rooted in the first, is the belief in the endemic character of "white racism." Some Blackists attribute the ills of blacks almost solely to "white racism," while others refuse to go quite that far. Some Blackists think that not only hasn' $t$ " white racism" diminished over the decades, it has actually grown more threatening; others claim to recognize that while "white racism" remains "potent," it has abated. Still, these degrees in understanding aside, all Blackists affirm - and must affirm - that "white racism" always has been and remains a genuine obstacle to black flourishing.

Third, the Blackist must never fail to give expression to some measure of indignation or rage regarding the near omnipresence of "white racism."

Fourth, the Blackist must be an unabashed champion of "social" or "racial justice." That is, he must not only support above and beyond all else the advancement of blacks; he must esteem as the most pivotal instrument toward this end a robust, activist federal government.

Finally, integral to Blackism is the notion of "racial authenticity." Racial authenticity - authentic blackness - requires nothing more or less than affirmation, by a biologically black person, of the tenets of Blackism.

If Blackism can be said to have a "High Priest," a quintessential spokesperson, it would be Malcolm X. Malcolm spent the overwhelming majority of his public career as a national minister for the Nation of Islam - a black supremacist cult deemed illegitimate by the Islamic world - condemning all whites as "devils." During his time with the Nation, as well as afterwards, Malcolm personified each of Blackism's tenets.

Malcolm would invoke "the authority of history" as he condemned whites for their transgressions against blacks and others. Whites, he charged, "stole our fathers and 
mothers from their culture of silk and satins and brought them to this land in the belly of a ship...." Ever since, "this blue-eyed devil" whose "time has about to run out" "has kept us in chains...." 25 Black people "didn't land on Plymouth Rock," Malcolm once said, but "Plymouth Rock landed" on blacks. ${ }^{26}$ American blacks - "twenty-two million black men" - have invested in their country, or been made to invest in it, "four hundred years of toil" - and yet "they are still today at the bottom of everything!" 27 The white race has "thrust" itself "into the position of leadership in the world" by way of "the use of naked physical power," through "conquering, killing, exploiting, pillaging, raping, bullying," and "beating." Throughout "his entire advance through history, he has been waving the banner of Christianity" in the one hand and, in the other, "the sword and the flintlock." 28

Malcolm not only reliably-inexhaustibly-drew upon his racialized "history" while expressing indignation over "white racism;" he also spared no occasion to assert his own racial authenticity while condemning other blacks as inauthentic. In Malcolm: The Life of a Man Who Changed Black America, Bruce Perry writes:

He [Malcolm] characterized Booker T. Washington as a "white man's nigger" and lampooned the NAACP as a "black body with a white head." Even Jackie Robinson and Joe Louis, whom he had idolized, were "stooges" for the white establishment....And despite his reluctant admiration for Martin Luther King, Jr., he portrayed him as a "chump, not a champ" .....

Malcolm, Perry notes, described black proponents of integration as "'Quislings' and 'Uncle Toms.'" He charged them with desiring "'white skins,'" depicted them "as blacks with white hearts," and lambasted them "for living in white neighborhoods and for being dependent on white money." Malcolm even referred to those activists who endured beatings at the hands of police officers as "'masochists.'" 29 The likes of Martin Luther King, Jr. and Roy Wilkins Malcolm ridiculed as "modern house Negroes" and "Toms." 30

It is true that upon being exiled from the Nation of Islam, Malcolm claimed to have rejected "racism." Yet while he abandoned "the white devil" and "Uncle Tom" rhetoric of his past, his efforts to have the United States tried and convicted by the United Nations on the charge that it was guilty of violating "the human rights" of its black citizens, as well as his related aim to extract reparations for American blacks, ${ }^{31}$ establish definitively that Malcolm's Blackist vision remained fully in tact.

The ideology of Blackism is the dominant ideology of the contemporary black intelligentsia. The most random selection of black-authored literature readily reveals this. Take, for instance, the notable academic, Cornel West. West correctly observes in the very first line of his discussion of "Identity and Race" in the fourth chapter of his Hope on a Tightrope: "We have to get our stories right from the very beginning," for "any discussion of race has to do with how we tell the story." 32 From the Blackist's 
perspective, the story is the " 244 years" that "black folk had no legal status, no social standing, no public worth whatever...." 33 It consists in " 244 years of white supremacist slavery, 87 years of white supremacist Jim and Jane Crow, and then another 40 years in which significant progress has been made." What this means is that since "stereotypes still cut deep," whites who want to affirm "the humanity" of blacks and other non-whites "must undergo a kind of conversion, metamorphosis, and transformation." ${ }^{34}$ Nothing less than "transformation" on the part of whites is needed because, "for the West," the idea "that black people are human beings" is "a revolutionary concept." 35

In keeping with Blackism's narrative of unrelenting "white supremacy," West remarks that this is "the real original sin" of America in which "African oppression" is grounded. White supremacy is "the precondition for a nation that could then be founded on the exploitation, subjugation, and hatred of African people." 36 It is "the white supremacy inside of black people" that "leads us to demean ourselves and devalue ourselves." 37

As for the notions of racial authenticity and "social justice," West is to the point: "'Black enough' always means 'bold enough." He elaborates: "Clarence Thomas," for instance, "is phenotypically, beautifully black." However, as "a right-wing conservative who sides with the strong against the weak," Thomas is "not bold enough." Thus, he is most definitely not black enough. ${ }^{38}$ In stark contrast, take Thurgood Marshall and Adam Clayton Powell. "Thurgood Marshall was a beautiful high-yellow black." But "he was black enough because he was bold enough. He didn't side with the strong, he sided with the weak." Powell "looked like a Puerto Rican," but blacks "loved him. How come? He was bold enough, which made him black enough." 39 Of course, being "bold enough" means sparing no occasion to advance the cause of black liberation or "social justice."

To put it another way, being "bold enough," being "black enough," means affirming Blackism.

\section{Conservatism}

If rationalism can be said to have a nemesis, it is that orientation that has come to acquire the name of "conservatism." In fact, given its endorsement of epistemological, ethical, and political philosophical conceptions that are antithetical to those espoused by rationalism, modern conservatism emerged as the response to the rationalistic excesses of Enlightenment. 


\section{Reason $\mathcal{E}$ Knowledge}

In his Reflections on the Revolution in France, Edmund Burke supplied for all subsequent generations as clear a statement of the conservative's reservations concerning reason as any that has been provided. Burke writes:

We are afraid to put men to live and trade each on his own private stock of reason; because we suspect that this stock in each man is small, and that individuals would be better to avail themselves of the general bank and capital of nations, and of ages. ${ }^{40}$

Burke articulates what some commentators have described as an epistemology grounded in "modesty." 41 He commends England's "men of speculation" on their resolve to desist from the enterprise of "exploding general prejudices" while using "their sagacity to discover the latent wisdom which prevails in them." 42 Upon examining these perennial prejudices, the wise opt for "the prejudice, with the reason involved," over "the naked reason," for the former "has a motive to give action to that reason, and an affection that will give it permanence." 43

On this conception, reason is constituted by the constraints of cultural tradition. While neither Burke nor any other conservative would deny that reason has access to "principles" or propositions, unlike rationalists, they recognize that knowledge is not only "technical," but "traditional," as Oakeshott describes it. Traditional knowledge "exists only in use;" it "is not reflective;" and it differs from technical knowledge in that it defies explicit formulation in propositional terms. ${ }^{44}$

\section{Morality and Political Philosophy}

The moral and political philosophies of the rationalist embody a universal and impartial perspective. They invariably consist of propositions, usually "principles" and/or "ideals," that are allegedly independent of any and every cultural and historical contingency. More often than not, these principles are held to specify "natural" or "human rights."

The conservative rejects this vision. The principles of an ideology are not timeless verities, but the abridgements of culturally-specifically traditions. "Circumstances," Burke declares, "give in reality to every political principle its distinguishing color and discriminating effect." It is "circumstances" that "render every civil and political scheme beneficial or noxious to mankind." 45 The problem with the rationalist's doctrine of "the rights of men" is the same problem that confronts all ideologies: an ideology is inflexible because its claims are categorical. "Against these [the rights of men] there can be no prescription; against these no argument is binding." The doctrine of "the rights of men" defy "temperament" and "compromise...." 46

Burke insists upon an inverse relationship between the cogency of the metaphysics of the rationalist and that of his political-morality. "The pretended rights of 
these theorists," he remarks, "are all extremes; and in proportion as they are metaphysically true, they are morally and politically false." 47 The "abstract perfection" of "the rights of men" is "their practical defect." In reality, our "liberties...vary with times and circumstances, and admit of infinite modifications" - a fact that precludes all attempts to establish them upon the "principle" of an "abstract rule." 48 Whatever sense there may (or may not) be in discussing "the original rights of man," it is "the civil social man, and no other," with which we concern ourselves in politics. Rights, thus, "is a thing "to be settled by convention." 49

The conservative tradition to which Burke gave rise is antithetical to modern rationalism. Epistemologically, ethically, and political-philosophically, it affirms precisely those tradition-centered conceptions of reason, morality, and the state that rationalism resolutely rejects.

We will now see that George Schuyler falls squarely within this tradition.

\section{George S. Schuyler}

George Schuyler was quite possibly among the greatest editorialists that America ever produced. Born in 1895 in Rhode Island, Schuyler lived in Syracuse, New York with his family until he was old enough to enlist in the United States Army. Upon the completion of World War I, he returned to civilian life, taking up residence in Harlem, where he remained until his death in 1977. It was during the decade of the 1920's when, from a thirst for intellectual stimulation rather than the appeal of its ideas, Schuyler joined the Socialist Party and began to travel within circles that would subsequently be identified with "the Harlem Renaissance." It was also during this decade that he began establishing for himself a rapidly expanding reputation as a writer. Throughout his life, in addition to authoring what has been called the first black science fiction novel, Black No More, Schuyler wrote as well for a plethora of other publications, black and white, including American Mercury, founded and edited by H.L. Mencken, the largest of literary giants of that time. Schuyler was a tireless champion for racial equality and a vehement opponent of communism. From 1922 until 1964, he was the editor for The Pittsburg Courier, the largest black newspaper publication in the country. In 1966, Schuyler composed his autobiography, Black and Conservative. ${ }^{50}$

If Malcolm X's can be said to be the quintessential voice of Blackism, then it is with no small measure of justice that we can say of Schuyler's that his is the voice of "antiBlackism." In fact, on more than one occasion, Schuyler and Malcolm X faced off with results that a remotely unprejudiced observer could only characterize as devastating for the latter.

During one round table radio discussion on "The Black Muslims in America" that transpired while Malcolm was still a member of The Nation of Islam, Schuyler pulled 
no punches. - neither with Malcolm, nor his other interlocutors. ${ }^{51}$ But given the topic of the exchange, it was primarily upon Malcolm that he set his sights.

Given his first opportunity to speak, Schuyler brilliantly and decisively laid waste to the ideology of Blackism espoused by Malcolm and The Nation of Islam. Its "antiChristian" and "anti-white" character, Schuyler began, is rooted in the erroneous belief "that white Christians were responsible for slavery in the world...." However, "this is one of the many falsehoods upon which this movement [The Nation] is founded," for it was "the Moslems" who "carried on slavery" for centuries upon centuries "before the white European Christians started it." 52

American blacks, Schuyler indignantly remarked, are "the healthiest" and "the wealthiest" blacks in the world. They "have the most property" and they are "the best educated" and "the best informed group of Negroes" on the planet - "and that includes all those in the Muslim countries." 53

Throughout this conversation on the Black Muslims - as throughout his lifeSchuyler continually repudiated the rationalist abstractionism of his Blackist opponents while remaining rooted in the empiricism characteristic of his conservatism. Urging Malcolm to return to "the field of reality," he pointed out to him that his claim that blacks are excluded from the country's economy is simply absurd on its face. Blacks buy and sell like everyone else, and in the case of a couple of hundred thousand black farmers particularly, they do much of the selling to whites. They are members of labor unions, not infrequently holding some of the highest positions. Malcolm's assertions to the contrary aside, they are not, "necessarily," "the last ones hired, first ones fired." 54 And even if it is true that the black unemployment rate is higher than that among whites, it is illegitimate to argue from this statistic to the conclusion that it is because they are "Negro" that blacks have higher rates of unemployment. ${ }^{55}$

The racial collectivities on which the Blackist's "history" depends simply - and abysmally-fail to do justice to the intricacies and nuances that an empirical consideration of reality reveals. In reality, while blacks, not unlike every other group of people that have ever existed, have indeed had to endure slavery and racial oppression, it is no less true that whites have gone to great lengths to assist blacks, both in America as well as elsewhere, in improving their condition. "If," Schuyler asked, "the white man has hated the Negro since he has been on the earth, why has the white man done so much to help the Negro?" Whites, for instance, "abolished the slave trade in Africa and from here to Africa...." Not a single Islamic state can claim to have done the same. Furthermore, whites have "set up schools and clinics and hospitals and asylums and colleges throughout all black Africa," yet "I don't know whether anybody can point out one Moslem college or university south of Egypt and Morocco in Africa" that has been established "for the education of black people." 
There are certainly whites who hate blacks, but the ideology of Blackism represented by the likes of Malcolm, like all rationalist abstractions, reduces the complexity of human experience and individuality to categorical simplicities. ${ }^{56}$

The poverty of nuance from which the ideological "history" of the Blackist suffers is evident not only in its glaring omission of the fact that slavery was being practiced in Africa by non-white Muslims for centuries and centuries before the first white Christian ever stepped foot on the Dark Continent. It is also reflected by its neglect of the inconvenient facts that, first, by every conventional social indicia, American blacks are far better off than the vast majority of people - of any color - who have ever lived; and, second, whites have labored, and continue to labor, indefatigably to aid blacks in America and Africa. The Blackist's ahistorical racial narrative also ignores the reality of the enslavement of whites generally and, specifically, the enslavement of whites in early America.

Schuyler correctly notes that it was not at all "unusual for unmixed Nordics [whites] to be sold into servitude, either in America or elsewhere." If whites in bondage "could not be sold on the wharves in Boston, New York or Philadelphia, they were marched manacled through the countryside to be sold to farmers for the passage money due the captain." Schuyler remarks upon the unbalanced coverage of black and white slavery, respectively:

It is the custom to illustrate every book on the slave trade with a picture of the manner in which the [African] slaves were packed into the holds. What is rarely shown is the manner in which European servants were similarly packed in like sardines, often with lower ceilings than the slave ships had. ${ }^{57}$

All of this, of course, is absent from the Blackist's racialized melodrama of White Oppression and Black Suffering.

Blackism, Schuyler believed, all too easily shaded into racism. As one who spent his entire life combating "the majority [white] attitude" toward blacks, an attitude that he describes as "morally wrong, nonsensical, unfair, un-Christian and cruelly unjust," 58 Schuyler found this deeply disturbing. In "The Rising Tide of Black Racism," he writes that Negroes were now in the process of acquiring the "racial fictions" of whites. "Having lugubriously wailed for generations over the cruelty of the color bar and the panting of the prideful so-called Aryans," Schuyler notes, black activists "more and more sound like the White Citizens Council agitators of yesteryear." 59 With alarming frequency, race is enlisted in the service of excusing "moral dereliction" and criminality ${ }^{60}$ as black "preachers...convert their pulpits into agitator's soapboxes spewing rabid racism...."

More disconcerting is that "this racist self-serving" is becoming ever more prevalent just as white racism appears to be on the wane. "The meanest motives have been 
attributed to all white people indiscriminately," he comments, "at the most promising period in race relations in our national history." Black activists exaggerate "every distemper...into an epidemic while white-dominated legislatures" are busy passing "numerous civil rights laws in excess of anything previously known" and "opportunities for education and employment unprecedented for Negro youth" are made available. Black "agitators" trade off "moderation and compromise, the essence of statesmanship," in favor of "self-denigration, absurd demands for preference, and unbecoming racial truculence...." This phenomenon poses "a real, present, and future danger" to the country, for in seeing "much-touted leaders rushing to cover up delinquency, immorality and crimes because the perpetrators are colored," black youth, rather than "think in terms of individual excellence," are likely to have their heads "contaminated by a cloud of racist propaganda." 61

In principle, the very notion of racial authenticity, of Blackism, Schuyler dismissed as a rationalist fiction. A multiracial universe promises to be as devoid of "self-made" races as the real world of numerous communities - "little platoons," as Burke referred to those institutions intermediate between governments and their citizens - promises to be devoid of "self-made" individuals. In "Negro-Art Hokum," Schuyler remarks: "Negro art there has been, is, and will be among the numerous black nations of Africa; but to suggest the possibility of any such development among the ten million colored people in this republic is self-evident foolishness." ${ }^{62}$

It is true that blacks gave rise to "those slave songs based on Protestant hymns and Biblical texts known as the spirituals, works songs and secular songs of sorrow and tough luck known as the blues," as well as "jazz" and "the Charleston," but there is nothing distinctively, much less uniquely, black or "Negro" about any of this. Rather, these are the "contributions of a caste" dwelling "in a certain section of the country" namely, the Southeast. These same art forms are "foreign to Northern Negroes, West Indian Negroes, and African Negroes." Thus, they no more reflect what today is often called "the black experience in America" than does "the music and dancing of the Appalachian highlanders or the Dalmatian peasantry" reflect "the Caucasian race."

Other genres of so-called "Negro art" are even more obviously Eurocentric. The "literature, painting, and sculpture" of black Americans "is identical in kind with the literature, painting, and sculpture of white Americans: that is, it shows more or less evidence of European influence." Schuyler offers the examples of "the dean of Aframerican literati," W.E.B. Du Bois, "the foremost Aframerican sculptor," Meta Warwick Fuller, and Henry Ossawa Tanner, "the most noted Aframerican painter...." Du Bois was educated at Harvard and at universities in Germany, Fuller is a one-time pupil of Rodin, and Tanner, being the "dean of painters in Paris," was at one time "decorated by the French Government." It is folly of the first order to hold up the work of these artists as embodying something uniquely, or even distinctively, black. 
That so-called "Negro art" is nothing of the kind is what we should expect once we consider that "the Aframerican is merely a lampblacked Anglo-Saxon." 63 How could he not be? After all, "the Aframerican is subject to the same economic and social forces that mold the actions and thoughts of the white Americans." 64 Given that blacks have been in America "for the last three hundred years," 65 and given that black and white Americans of comparable cultural and economic circumstances have "similar furniture, literature, and conversation," it should come as no surprise that the arts produced by blacks should "reveal the psychology and culture of their environment" - not "their color." 66

In addition to his historical and tradition-centered views on race relations and racial identity, Schuyler's opposition to the rationalism of the Blackist found expression as well in his orientation toward liberty-an orientation that in turn reflected his conception of change.

In 1963, when the historic Civil Rights Act of the following year was still just a bill, Schuyler came out forcefully against it. Though each of the multiple lines of attack that he launched is distinct from the others, they all speak to the various ways in which the bill reflects and advances an unmistakably rationalist-i.e. utopian-agenda. Its architects are typical rationalists inasmuch as they presumably believe both that legislation is necessary if constructive social change is to be had and that legislation is the sole way to affect rapid social change. However, on both counts, they couldn't be more mistaken.

The propensity "to speed social change by law," a predilection that distinguishes all relatively young countries like the United States that suffer from "a passion for novelty," the offspring of the union of "moral indignation" and the desire for "social reform," is rooted in the bogus "assumption that by such legerdemain it is possible to make people better by force." Yet although this strikes its advocates as both possible and desirable, this piece of self-delusion "has been the cause of much misery and injustice throughout the ages." 67 In reality, "it is almost axiomatic that it takes lots of time to change social mores, especially with regard to such hardy perennials as religion, race and nationality, to say nothing of social classes." 68

Schuyler acknowledges that (as of 1963) changes in race relations have been "very slow;" but he is also quick to point out that they have been "marked" - particularly during the last 25 years or so preceding the composition of his argument. Furthermore, these changes are of such quality that no other country on Earth can claim to have given rise to anything remotely comparable to them as far as dealings with their own racial minorities are concerned. In terms of "education, housing, health, voting and economic well-being," black Americans by far and away eclipse the material condition of the racial minorities of other societies, including and especially those societies - like India, Soviet Russia, Japan, Indonesia, Australia, and countries 
throughout Latin America - "whose spokesmen criticize and excoriate the United States...." Schuyler draws our attention to the fact that civil rights laws, whether "state or federal, have had little to do with" any of this progress in America. Moreover, such laws "have been enforced and accepted only when the dominant majority acquiesced;" otherwise, they "have generally lain dormant in the law books."

In other words, it is not legislation that inspires human conduct; rather, it is "custom" that "has dictated the pace of compliance" with legislation.

There is one other critical respect-perhaps, from Schuyler's perspective, the most critical respect-in which the proposed civil rights legislation betrays its debt to rationalism. What would become the Civil Rights Act of 1964 relies upon an abstract notion of liberty. Schuyler knew that the liberty to which Americans of all backgrounds have grown accustomed - the liberty with which they were, or at least claimed to be, in love - is not some abstract, timeless universal principle or ideal but a concrete, culturally-specific complex of institutional arrangements guaranteeing a vast diffusion of power and authority. It was precisely because federal civil rights laws of the sort being proposed threatened to upset this arrangement that he invoked this as "the principal" consideration against it.

A federal civil rights law "is... another encroachment by the central government on the federalized structure of our society." Such a law, though intended to "improve the lot of a tenth of the population," will render it that much easier for the government to "enslave the rest of the populace," for under it, "the individual everywhere" will be "told what he must do and what he cannot do, regardless of the laws and ordinances of his state or community." But "this is a blow at the very basis of American society," a society "founded on state sovereignty and individual liberty and preference." Schuyler writes: "We are fifty separate countries...joined together for mutual advantage, security, advancement, and protection. It was never intended that we should be bossed by a monarch, elected or born." Schuyler concludes: "When this happens, the United States as a free land will cease to exist." 69

\section{Conclusion}

Schuyler's critics' judgments to the contrary notwithstanding, Schuyler did not, as Jeffrey Leak remarks, abandon "racial justice" in favor of "extreme forms of conservative ideology;"70 much less was he a "race traitor."71 As I have argued here, Schuyler's critics, like Jeffrey Leak, have grossly oversimplified Schuyler in viewing him as an ultimately insensitive-and insensible-ideologue when it came to race relations in America. Rather, Schulyer was an adherent of a classical conservative intellectual tradition that was born of resistance to the rationalistic excesses of Enlightenment. His epistemic, ethical, and political conceptions-specifically, his tradition-centered philosophies of race, identity, and liberty - were molded within the 
context of this centuries-old contest, for it was against the latest manifestation of rationalism - Blackism - that Schuyler found himself laboring mightily. 


\section{End Notes}

1. Rac[e]ing to the Right. Ed. Jeffrey B. Leak (Knoxville: University of Tennesseeress, 2001).

2. Ibid., ix.

3. Ibid., xi.

4. Ibid., xxxvi. Leak quotes E. Franklin Frasier's description of Schuyler.

5. Cornel West's, Hope on a Tightrope. (Carlsbad: Hay House, 2008).

6. Rac[e]ing to the Right. Ed. Jeffrey B. Leak (Knoxville: University of Tennessee Press, 2001), $x$.

7. Ibid., xxxix.

8. Ibid., xiii.

9. Ibid., xli.

10. Ibid., xxxiii.

11. Michael Oakeshott's, "Rationalism in Politics," in Rationalism in Politics and Other Essays (Indianapolis: Liberty Fund, 1962), 14-15.

12. Ibid., 15.

13. Ibid., 12.

14. Ibid., 15.

15. Ibid., 11.

16. Ibid., 16.

17. Ibid., 15.

18. Ibid., 40.

19. Ibid., 33.

20. Ibid., 41.

21. Ibid., 8. 
22. Ibid., 11.

23. Ibid., 10.

24. Ibid., 11.

25. Bruce Perry. Malcolm: The Life of a Man Who Changed Black America (Barrytown: Station Hill Press, 1992), 175-176.

26. Ibid., 232.

27. Ibid., 363.

28. Ibid., 424.

29. Ibid., 203.

30. Manning Marable. Malcolm X: A Life of Reinvention (New York: Viking Adult, 2011), 264-265.

31. That Malcolm fought for these causes is common knowledge. Manning Marable is among those of his biographers who does a particularly outstanding job of showing how the logic of Malcolm's evolving globalist vision - his "PanAfricanism" - informed his support for them. See Marble's, Malcolm X: A Life of Reinvention (New York: Viking Adult, 2011).

32. Cornel West. Hope on a Tightrope (Carlsbad: Hay House, 2008), 43.

33. Ibid., 44.

34. Ibid., 45.

35. Ibid., 47.

36. Ibid., 46.

37. Ibid., 50.

38. Ibid., 60-61.

39. Ibid., 61.

40. Edmund Burke, "Reflections on the Revolution in France," in The Portable Edmund Burke. Ed. Isaac Kramnick (New York: Penguin Books, 1999), 451-452. 
41. Jerry Z. Muller's, Conservatism: An Anthology of Social and Political Thought from David Hume to the Present (Princeton: Princeton University Press, 1997).

42. Edmund Burke, "Reflections on the Revolution in France," in The Portable Edmund Burke. Ed. Isaac Kramnick (New York: Penguin Books, 1999), 451.

43. Ibid., 452.

44. Michael Oakeshott, "Rationalism in Politics," in Rationalism in Politics and Other Essays (Indianapolis: Liberty Fund, 1962), 12.

45. Edmund Burke, "Reflections on the Revolution in France," in The Portable Edmund Burke. Ed. Isaac Kramnick (New York: Penguin Books, 1999). 417.

46. Ibid., 440 .

47. Ibid., 443.

48. Ibid., 442.

49. Ibid., 441.

50. For his complete biography, see George S. Schuyler's, Black and Conservative: The Autobiography of George S. Schuyler (New Rochelle: Arlington House Publishers, 1966).

51. Black scholar of religion and author of the first study of the Nation of Islam, C. Eric Lincoln, and famed black novelist, James Baldwin.

52. George S. Schuyler, "The Black Muslims in America," in Rac[e]ing to the Right. Ed. Jeffrey Leak (Knoxville: University of Tennessee Press, 2001), 74.

53. Ibid., emphasis added. Incidentally, C. Eric Lincoln conceded that Schuyler was correct on this score.

54. Ibid., 81-82.

55. Ibid., 82.

56. Ibid., 83.

57. George S. Schuyler, "The Future of the American Negro," in Rac[e]ing to the Right. Ed. Jeffrey Leak (Knoxville: University of Tennessee Press, 2001), 111. 
58. George S. Schuyler, "The Case Against the Civil Rights Bill," in Rac[e]ing to the Right. Ed. Jeffrey Leak (Knoxville: University of Tennessee Press, 2001). 98.

59. George S. Schuyler, "The Rising Tide of Black Racism," in Rac[e]ing to the Right. Ed. Jeffrey Leak (Knoxville: University of Tennessee Press, 2001), 106.

60. Ibid., 107-108.

61. Ibid., 108.

62. George S. Schuyler, "Negro-Art Hokum," in Rac[e]ing to the Right. Ed. Jeffrey Leak (Knoxville: University of Tennessee Press, 2001), 13.

63. Ibid., 14.

64. Ibid., 15.

65. Ibid., 14 .

66. Ibid., 15.

67. George S. Schuyler, "The Case Against the Civil Rights Bill," in Rac[e]ing to the Right. Ed. Jeffrey Leak (Knoxville: University of Tennessee Press, 2001), 97 emphasis original.

68. Ibid., 97-98.

69. Ibid., 103. 


\section{Bibliography}

Edmund Burke, "Reflections on the Revolution in France," in The Portable Edmund Burke. Ed. Isaac Kramnick (New York: Penguin Books, 1999)

Manning Marable. Malcolm X: A Life of Reinvention (New York: Viking Adult, 2011), 264-265.

Jerry Z. Muller, Conservatism: An Anthology of Social and Political Thought from David Hume to the Present (Princeton: Princeton University Press, 1997).

Michael Oakeshott, "Rationalism in Politics," in Rationalism in Politics and Other Essays (Indianapolis: Liberty Fund, 1962), 14-15.

Bruce Perry. Malcolm: The Life of a Man Who Changed Black America (Barrytown: Station Hill Press, 1992), 175-176.

Rac[e]ing to the Right. Ed. Jeffrey B. Leak (Knoxville: University of Tennesseeress, 2001).

George S. Schuyler, Black and Conservative: The Autobiography of George S. Schuyler (New Rochelle: Arlington House Publishers, 1966).

George S. Schuyler, "The Black Muslims in America," in Rac[e]ing to the Right. Ed. Jeffrey Leak (Knoxville: University of Tennessee Press, 2001), 74.

George S. Schuyler, "The Future of the American Negro," in Rac[e]ing to the Right. Ed. Jeffrey Leak (Knoxville: University of Tennessee Press, 2001),

George S. Schuyler, “The Case Against the Civil Rights Bill," in Rac[e]ing to the Right. Ed. Jeffrey Leak (Knoxville: University of Tennessee Press, 2001). 98.

George S. Schuyler, "The Rising Tide of Black Racism," in Rac[e]ing to the Right. Ed. Jeffrey Leak (Knoxville: University of Tennessee Press, 2001), 106.

George S. Schuyler, "Negro-Art Hokum," in Rac[e]ing to the Right. Ed. Jeffrey Leak (Knoxville: University of Tennessee Press, 2001), 13.

Cornel West, Hope on a Tightrope. (Carlsbad: Hay House, 2008). 


\section{E-LOGOS}

\section{ELECTRONIC JOURNAL FOR PHILOSOPHY}

Ročník/Year: 2014 (vychází průběžně/ published continuously)

Místo vydání/Place of edition: Praha

ISSN 1211-0442

Vydává/Publisher:

Vysoká škola ekonomická v Praze / University of Economics, Prague

nám. W. Churchilla 4

Czech Republic

13067 Praha 3

IČ: 61384399

Web: http://e-logos.vse.cz

Redakce a technické informace/Editorial staff and technical information:

Miroslav Vacura

vacuram@vse.cz

Redakční rada/Board of editors:

Ladislav Benyovszky (FHS UK Praha, Czech Republic)

Ivan Blecha (FF UP Olomouc, Czech Republic)

Martin Hemelík (VŠP Jihlava, Czech Republic)

Angelo Marocco (Pontifical Athenaeum Regina Apostolorum, Rome, Italy)

Jozef Kelemen (FPF SU Opava, Czech Republic)

Daniel Kroupa (ZU Plzeň, Czech Republic)

Vladimír Kvasnička (FIIT STU Bratislava, Slovak Republic)

Jaroslav Novotný (FHS UK Praha, Czech Republic)

Jakub Novotný (VŠP Jihlava, Czech Republic)

Ján Pavlík (editor-in-chief) (VŠE Praha, Czech Republic)

Karel Pstružina (VŠE Praha, Czech Republic)

Miroslav Vacura (executive editor) (VŠE Praha, Czech Republic) 